\title{
Analisis Kepatuhan Wajib Pajak Kendaraan Bermotor Berdasarkan Peraturan Gubernur No 44 Tahun 2017: Studi pada Badan Pengelola Pendapatan Daerah Provinsi Jawa Tengah
}

http://journal.umy.ac.id/index.php/jati DOI: 10.18196/jati.020113

DATA ARTIKEL:

Diterima: 24 Juni 2019

Direviu: 25 Juni 2019

Direvisi: 5 Juli 2019

Disetujui: 1 Agustus 2019

\author{
PRATOMO CAHYO KURNIAWAN*, FIKA AZMI \\ STIE Bank BPD Jateng \\ *Email korespodensi : pratomokurniawan8@gmail.com
}

TOPIK ARTIKEL:

Akuntansi Sektor Publik obtained in this study were collected through direct observation in the field. The data analysis technique used is by conducting activities interactively. Data analysis in qualitative research was carried out at the time of data collection. The results of the study indicate that the level of tax compliance is very important in order to increase regional income. The government needs to improve services, make transparency, and improve facilities and infrastructure in paying taxes.

Keywords: Taxes, Motivation, Increased Income, Public Services.

SITASI ARTIKEL:

Kurniawan, P.C., \& Azmi, Fika (2019). Analisis Kepatuhan Wajib Pajak Kendaraan Bermotor Berdasarkan Peraturan Gubernur No. 44 Tahun 2017: Studi pada Badan Pengelola Pendapatan Daerah Provinsi Jawa Tengah. Jati: Jurnal Akuntansi Terapan Indonesia, 2(1), 14-24

\section{PENDAHULUAN}

Pembangunan nasional sudah ditetapkan di dalam pembukaan UUD 1945. Realisasi pembangunan nasional yang terukur dibutuhkan ketersediaan dana yang besar. Setiap daerah telah diberi kewenangan untuk mengatur perekonomian masing - masing. Setiap pemerintah Provinsi, pemkot, maupun pemkab dapat membiayai sendiri setiap kegiatan operasionalnya secara efektif, efisien dan fokus untuk mencapai tujuan. Pemerintah daerah harus pandai mengelola Pendapatan Asli daerah
ABSTRAK: This study aims to discuss Taxpayer Compliance, Factors that can influence it, and Government Efforts to Motivate Taxpayers in relation to Regulation No. 44 of 2017. This research is used to obtain a comprehensive understanding of the essence of Taxpayer Compliance and Factors which affects the Taxpayer Compliance Level to increase provincial government revenues from $P K B$ Eु $B B N K B$. This research is a qualitative research. Data 
(PAD) untuk membiayai roda pemerintahannya agar tetap berjalan (Utami, 2014).

Pendapatan Asli daerah (PAD) di era otonomi daerah menjadi hal yang penting untuk pengembangan daerah. Kepala Daerah yang mampu mengelola PAD akan lebih mudah mengembangkan daerahnya. Berdasarkan UU nomor 22 tahun 1999 pasal 79 bahwa sumber pendapatan asli daerah terdiri dari hasil pajak daerah, retribusi daerah, laba BUMD, dan pendapatan lain-lain yang sah. Pajak daerah adalah transfer kekayaan dari masyarakat pada kas negara untuk membiayai pengeluaran operasional yang rutin dan kelebihannya digunakan untuk Public Investment. Kaho (2002) mengemukakan pajak daerah adalah pungutan yang dilakukan daerah sesuai peraturan yang telah ditetapkan untuk membiayai kegiatan daerah.

Undang - Undang nomor 18 tahun 1999 Pasal 2 ayat (1) dan (2) menyebutkan bahwa jenis pajak daerah dibagi menjadi dua yaitu pajak dari daerah Tingkat satu yang terdiri dari pajak kendaraan bermotor, bea balik nama kendaraan bermotor, dan pajak bahan bakar kendaraan bermotor. Kemudian jenis pajak daerah Tingkat dua terdiri dari pajak restoran dan hotel, pajak reklame dan hiburan, penerangan jalan umum, pengambilan dan pengelolaan bahan galian golongan C, serta pemanfaatan air bawah tanah dan air permukaan. Daerah Tingkat satu tarif pajaknya diatur melalui peraturan pemerintah (PP) yang berlaku di seluruh. Sedangkan daerah Tingkat dua ditetapkan melalui peraturan daerah (perda).

Jenis pajak yang berpotensi semakin meningkat seiring dengan kemajuan teknologi dan standar kebutuhan sekunder menjadi primer adalah pajak kendaraan bermotor (PKB). Undang - Undang Nomor 28 Tahun 2009 menyatakan Pajak Kendaraan Bermotor merupakan pajak dari kepemilikan dan atau penguasaan kendaraan ber-motor. Kendaraan bermotor merupakan semua kendaraan yang mempunyai roda dengan gande-ngan yang digunakan pada semua jalan darat, digerakkan dengan peralatan teknik seperti motor atau peralatan lainnya yang memiliki fungsi mengubah sumber daya energi tertentu menjadi tenaga gerak yang mampu menggerakkan ken-daraan, termasuk alat - alat besar serta alat berat dimana dioperasikan menggunakan roda dan motor yang tidak melekat secara permanen serta kenda-raan bermotor yang digunakan di air.

Pengenaan Pajak Kendaraan Bermotor didasarkan pada ketentuan Undang - Undang Nomor 28 tahun 2009 pasal 3-8. Pajak kendaraan bermotor yang diterapkan di daerah provinsi didasarkan pada perda provinsi tersebut yang digunakan sebagai landasan hukum operasional dan teknis pelaksanaan pengenaan dan pemungutan pajak kendaraan bermotor di daerah provinsi tersebut serta keputusan gubernur tentang pajak kendaraan bermotor sebagai aturan pelaksanaan peraturan daerah tentang PKB di provinsi tersebut.

Berdasarkan data BPS (2019), Provinsi Jawa Tengah merupakan provinsi yang memiliki kepadatan penduduk terbesar ketiga setelah Jabar dan Jatim, luas wilayahnya mencapai $34.864 \mathrm{~km}^{2}$ sehingga penduduk Jawa Tengah termasuk padat. Demografi ini dapat memicu peningkatan kegiatan perekonomian di Jawa Tengah. Realisasi dan target jumlah pendapatan PKB di Jawa Tengah harus meningkat. Jawa Tengah memiliki 35 Kabupaten/ Kota dimana pembagian wilayah pengenaan pajak kendaraan bermotor di Jawa Tengah dikelola oleh masing - masing UPPD wilayah kabupaten/kota. Berikut daftar UPPD di Provinsi Jateng :

Tabel 1

Daftar UPPD

\begin{tabular}{|l|l|}
\hline NO & \multicolumn{1}{|c|}{ Koordinator UPPD } \\
\hline 1 & Koordinator Semarang \\
\hline 2 & Koordinator Surakarta \\
\hline 3 & Koordinator Pati \\
\hline 4 & Koordinator Pekalongan \\
\hline 5 & Koordinator Banyumas \\
\hline 6 & Koordinator Kedu \\
\hline
\end{tabular}

Sumber : DPPAD, 2019

Tabel 2

Penerimaan PKB dan BBNKB

\begin{tabular}{|l|l|l|l|l|}
\hline NO & $\begin{array}{l}\text { Jenis } \\
\text { Penerimaan }\end{array}$ & $\begin{array}{l}\text { Realisasi } \\
2017\end{array}$ & $\begin{array}{l}\text { Realisasi } \\
2018\end{array}$ & $\begin{array}{l}\text { Realisasi } \\
2019 \\
\text { (maret) }\end{array}$ \\
\hline 1 & PKB & $3.7 \mathrm{~T}$ & $3.94 \mathrm{~T}$ & $1.02 \mathrm{~T}$ \\
\hline 2 & BBNKB & $2.97 \mathrm{~T}$ & $3.06 \mathrm{~T}$ & 778 Juta \\
\hline
\end{tabular}

Sumber : DPPAD, 2019

Setiap koordinator UPPD membawahi beberapa UPPD (Samsat) Kabupaten/Kota yang bertanggung jawab atas penarikan Pajak Kendaraan Bermotor (PKB). Nilai pendapatan PKB setiap tahun mengalami fluktuasi, dan memiliki kontribusi besar terhadap Pendapatan Asli Daerah (PAD) Provinsi Jawa Tengah. Informasi mengenai PKB dan BBNKB tercantum dalam tabel 2.

Faktor - faktor yang dapat mempengaruhi besaran PKB dan BBNKB antara lain: 1) Ada atau tidaknya penetapan surat yang terkait dengan PKB, kinerja SAMSAT, SAMSAT keliling, Aktivitas jual beli Kendaraan Bermotor, Jumlah dealer penjualan kendaraan bermotor utamanya kendaraan roda dua yang diberikan insentif berupa kemudahan kredit, kemudahan angsuran, kemudahan uang muka, ser- 
ta Kualitas infrastruktur jalan provinsi yang menghubungkan kabupaten dan kota di provinsi Jawa Tengah. 2) Sistem Target yang ditetapkan oleh pemerintah daerah yang mengakibatkan biaya pungutan yang besar terhadap PKB dan BBNKB. 3) Lemahnya pengendalian dalam perencanaan, pelaksanaan, pengawasan penerimaan dan pengeluaran daerah yang dapat merugikan pembangunan daerah.

Pemerintah Provinsi Jawa Tengah berupaya mendorong kesadaran masyarakat untuk membayar pajak daerah terutama PKB dan BBNKB diantaranya dengan menerbitkan Pergub no 44 tahun 2017 tentang Pembebasan BBNKB dan Pembebasan Sanksi Administratif PKB. Kebijakan ini diterbitkan karena banyaknya pemilik kendaraan bermotor yang menunggak pembayaran PKB dan BBNKB dengan berbagai macam alasan karena kelalaian, keengganan, ketidakmampuan bayar, ketakutan membayar, dan merasa kendaraannya sudah tua sehingga tidak perlu membayar PKB dan BBNKB.

Data BPPD menyebutkan bahwa sebanyak 32 persen dari total jumlah kendaraan bermotor di Jawa Tengah menunggak PKB. Mayoritas penunggak PKB adalah kendaraan bermotor jenis roda dua. Pemprov Jawa Tengah seharusnya bisa mendapatkan penerimaan pendapatan dari sektor pajak, namun dilihat dari realisasinya pemerintah tidak dapat memaksimalkan pendapatan karena terdapat kendala seperti kesadaran dan kepatuhan wajib pajak dalam membayar PKB.

Menurut Chau dan Leung (2009) mengemukakan bahwa tingkat kepatuhan pajak merupakan faktor yang mempengaruhi pendapatan suatu negara. Kepatuhan pajak merupakan kewajiban wajib pajak dalam memenuhi kewajiban perpajakan dan melaksanakan hak perpajakan sesuai dengan peraturan perundangan. Kepatuhan pajak adalah sebuah fenomena yang dilihat dari banyak perspektif yang sangat kompleks.

Franzoni, dkk (2013) menyatakan bahwa kepatuhan pajak dapat dipengaruhi dari beberapa faktor yang dilihat dari beberapa perspektif : kecenderungan terhadap instansi publik (Direktorat Jendral Pajak), sistem yang adil yang dapat dirasakan wajib pajak, pandangan tentang keadilan, dan sanksi yang tegas dari undang - undang. Kurangnya pemahaman serta pengetahuan mengenai pajak dapat berakibat pada kesadaran masyarakat yang berkurang untuk membayar pajak. Masyarakat menjadi kurang tertarik untuk membayar pajak karena tidak diberikan timbal balik secara langsung dari negara.

Rahayu (2010) kualitas pengetahuan pajak yang baik dapat mempengaruhi kepatuhan wajib pajak (WP) menunaikan kewajiban perpajakannya. Tingkat pemahaman serta pengetahuan WP yang tinggi, akan mempermudah bagi WP dalam mengerti aturan perpajakan dan menjalankan kewajiban pajaknya. Susanto (2012) menyatakan bahwa masyarakat perlu merubah pemikirannya seperti prasangka buruk, baik terhadap petugas agar pelayanan semakin prima.

Feld dan Frey (2007) mengemukakan masyarakat secara otomatis membayar pajak jika mereka puas dengan pelayanan publik yang sebanding dengan yang mereka bayarkan, pemerintah yang adil, dan proses perpajakan yang jelas dari pemerintah. Selain pelayanan yang dilakukan dengan baik diperlukan juga adanya sanksi yang menjadi pengontrol bagi wajib pajak, sanksi perpajakan yang akan diterima WP adalah faktor lainnya yang dapat mempengaruhi peningkatan kepatuhan wajib pajak kendaraan bermotor.

Berdasarkan fakta di atas, menarik minat peneliti untuk meneliti lebih lanjut "Analisis Kepatuhan Wajib Pajak Kendaraan Bermotor Dengan Kebijakan Penghapusan Denda Pajak dan Biaya Balik Nama Kendaraan Bermotor Berdasarkan Surat Keputusan Gubernur No 44 Tahun 2017 (Studi Pada Badan Pengelola Pendapatan Daerah Provinsi Jawa Tengah).

Penelitian ini diharapkan dapat memberikan pemahaman secara komprehensif mengenai Faktor - Faktor yang dapat mempenga-ruhi Tingkat Kepatuhan Wajib Pajak, serta dapat digunakan untuk memberikan masukan kepada Pemerintah Provinsi Jawa Tengah untuk meningkatkan pendapatan dari Pajak Kendaraan Bermotor \& Biaya Balik Nama Kendaraan Bermotor. Proses pengumpulan data dalam penelitian ini menggunakan dokumen, wawancara dan studi kepustakaan.

\section{Pajak Kendaraan Bermotor (PKB) dan Bea Balik Nama Kendaraan Bermotor (BBNKB)}

Kendaraan bermotor merupakan semua jenis kendaraan beroda dua atau lebih dengan gandengan yang digunakan di jalan darat, dan digerakkan oleh peralatan berbentuk motor atau peralatan lainnya. Pajak Kendaraan Bermotor meru-pakan pajak yang diambil dengan dasar kepemilikan atau penguasaan kendaraan bermotor. Bea Balik Nama Kendaraan Bermotor merupakan pajak yang dipungut atas setiap penyerahan kendaraan bermotor dalam hak milik.

\section{Subyek dan Obyek Pajak Kendaraan Bermotor}

Objek Pajak Kendaraan Bermotor merupakan kepemilikan dan/atau penguasaan Kendaraan 
Bermotor. Subjek Pajak Kendaraan Bermotor merupakan orang pribadi atau Badan yang menguasai dan atau memiliki Kendaraan Bermotor. Wajib Pajak Kendaraan Bermotor merupakan orang pribadi atau yang mempunyai Kendaraan Bermotor. Hal mengenai Wajib Pajak Badan, kewajiban pajaknya diurus oleh pengurus atau kuasa Badan tersebut.

\section{Dasar Pengenaan \& Tarif Kendaraan Bermotor}

Dasar pengenaan Pajak Kendaraan Bermotor adalah hasil perkalian dari 2 (dua) unsur pokok ; a) Nilai Jual Kendaraan Bermotor ; b)bobot yang mencerminkan secara relatif tingkat kerusakan jalan dan/atau pencemaran lingkungan akibat penggunaan Kendaraan Bermotor. Khusus untuk Kendaraan Bermotor yang digunakan di luar jalan umum, termasuk alat-alat berat dan alat-alat besar serta

kendaraan di air, dasar pengenaan Pajak Kendaraan Bermotor adalah Nilai Jual Kendaraan Bermotor. Bobot sebagaimana dimaksud dinyatakan dalam koefisien yang nilainya 1 (satu) atau lebih dari 1 (satu), dengan pengertian sebagai berikut: a) koefisien = 1 (satu) berarti kerusakan jalan dan/atau pencemaran lingkungan dari penggunaan Kendaraan Bermotor tersebut dianggap masih dalam batas toleransi; b) koefisien > 1 (satu) berarti penggunaan Kendaraan Bermotor tersebut dianggap melewati batas toleransi.

Nilai Jual Kendaraan Bermotor ditentukan dari Harga Pasaran Secara Umum atas suatu Kendaraan Bermotor. Harga Pasar yang dimaksud adalah harga rata - rata yang didapat dari berbagai sumber data yang akurat. Nilai Jual Kendaraan Bermotor disepakati berdasarkan Harga Pasaran Umum pada minggu pertama di bulan Desember Tahun Pajak sebelumnya. Jika Harga Pasaran Umum suatu Kendaraan Bermotor tidak diketahui.

Tarif Pajak Kendaraan Bermotor pribadi badan ditetapkan sebesar 1,5\% (satu koma lima persen) untuk ke-pemilikan kendaraan pertama. Tarif Pajak Kendaraan Bermotor pribadi dihitung secara progresif dan ditetapkan sebagai berikut : a) Kepemilikan kendaraan bermotor pertama yaitu 1,5 $\%$; b) Kepemilikan kendaraan bermotor kedua yaitu $2 \%$; c) Kepemilikan kendaraan bermotor ketiga yaitu 2,5\% ; d) Kepemilikan kendaraan bermotor keempat yaitu $3 \%$; e) Kepemilikan kendaraan bermotor kelima yaitu 3,5\%;

Tarif Pajak Kendaraan Bermotor umum, lembaga sosial keagamaan, Pemerintah $\mathrm{Pu}$ sat/TNI/POLRI, dan Pemerintah Daerah ditetapkan sebagai berikut: a) Kendaraan Bermotor umum sebesar $1 \%$; b) Kendaraan Bermotor lembaga sosial keagamaan, Pemerintah Pusat/TNI/POLRI, Pemerintah Daerah sebesar 0,5\%. Tarif Pajak Kendaraan
Bermotor alat - alat berat dan alat - alat besar sebesar $0,1 \%$ dan paling tinggi sebesar $0,2 \%$. Tarif Pajak Kendaraan di air sebesar $1,5 \%$.

\section{METODE PENELITIAN}

Penelitian merupakan rencana penelitian yang mencakup hal yang dilakukan peneliti. Penelitian ini merupakan penelitian kualitatif. Data yang diperoleh pada penelitian ini dihimpun melalui observasi secara langsung di lapangan. Subyek pada penelitian ini yaitu Bagian Perencanaan dan Pengembangan Badan Pengelolaan Pendapatan Daerah (BPPD) Provinsi Jawa Tengah. Obyek pada penelitian ini adalah pokok persoalan yang akan diteliti untuk mendapatkan data secara lebih terarah. Adapun obyek penelitiannya yaitu :

(1) Faktor - Faktor yang dapat mempengaruhi Kepatuhan dalam membayar Pajak Kendaraan Bermotor dalam kaitannya dengan Kebijakan Penghapusan Denda Pajak dan Biaya Balik Nama Kendaraan Bermotor Berdasarkan pada Surat Keputusan Gubernur No. 44 Tahun 2017 di Badan Pengelolaan Pendapatan Daerah (BPPD) Provinsi Jawa Tengah; (2) Upaya yang dilakukan oleh Badan Pengelolaan Pendapatan Daerah (BPPD) Provinsi Jawa Tengah dalam memotivasi masyarakat untuk membayar Pajak Kendaraan Bermotor.

\section{Teknik Pengumpulan Data \& Teknik Analisis Data}

Peneliti menggunakan teknik pengumpulan data untuk penelitian ini yaitu;

(1) Teknik pengumpulan data melalui studi pustaka digunakan untuk mendapatkan teori teori, pendapat - pendapat yang terdapat dalam media. Studi pustaka berasal dari buku, jurnal ilmiah, dan data media lainnya; (2) Observasi difokuskan sebagai upaya peneliti untuk mengumpulkan data dan informasi dari sumber data primer dengan melakukan pengamatan secara langsung (Sugiyono, 2010). Teknik ini digunakan untuk memperoleh data mengenai realisasi dan target anggaran penerimaan Pajak Kendaraan Bermotor dan Bea Balik Nama Kendaraan Bermotor di Pemerintah Provinsi Jawa Tengah; (3) Wawancara digunakan untuk menggali lebih dalam mengenai data yang diperoleh dari hasil observasi, sehingga tidak ada informasi yang terputus antara yang dilihat, didengar, dan dicatat (Sugiyono, 2010). Teknik ini digunakan untuk memperoleh Gambaran Penerimaan Pajak Kendaraan Bermotor dan Bea Balik Nama Kendaraan Bermotor di Pemerintah Provinsi Jawa Tengah. Teknik analisis data yang digunakan yaitu dengan melakukan aktivitas secara interaktif. Analisis data dalam penelitian kualitatif dilakukan pada saat pengumpulan data 
berlangsung. Aktivitas yang dilakukan yaitu data reduction, data display, dan conclusion drawing/verifications (Sugiyono, 2010).

\section{HASIL \& PEMBAHASAN}

Faktor - Faktor yang Mempengaruhi Kepatuhan Membayar Pajak Kendaraan Bermotor dalam Kaitannya dengan Kebijakan Penghapusan Denda Pajak dan Biaya Balik Nama Kendaraan Bermotor Berdasarkan pada Surat Keputusan Gubernur No. 44 Tahun 2017.

Usaha untuk meningkatkan tingkat kepatuhan pajak dan mempertahankan tingkat kepatuhan saat ini merupakan isu yang menjadi perhatian para pembuat kebijakan baik di negara maju maupun berkembang. Masalah utama yang paling penting adalah mendorong tingkat kepa-tuhan wajib pajak. Hal ini dikarenakan tingkat kepatuhan pajak secara tidak langsung mempe-ngaruhi ketersediaan pendapatan untuk belanja. Kepatuhan wajib pajak merupakan faktor paling penting bagi peningkatan pajak, maka perlu secara intensif dikaj tentang faktor-faktor yang mempengaruhi kepatuhan wajib pajak, khususnya dalam membayar pajak kendaraan bermotor (PKB) di wilayah Provinsi Jawa Tengah.

Kebijakan Penghapusan Denda Pajak Kendaraan Bermotor dan Biaya Balik Nama Kendaraan Bermotor yang dituangkan dalam Pergub No 44 tahun 2017. Kebijakan penghapusan denda diharapkan dapat memberikan kemudahan serta meringankan beban PKB yang harus dibayarkan oleh masyarakat akibat dari keterlambatan pembayaran PKB. Masyarakat hanya membayarkan besaran pajaknya saja tanpa dibebani oleh denda. Kebijakan Pembebasan Biaya Balik Nama Kendaraan Bermotor (BBNKB) diharapkan menjadi stimulus untuk masyarakat yang ingin memindahkan kendaraannya dari luar provinsi. Bagi pemerintah provinsi ini akan menjadi tambahan pendapatan karena kendaraan tersebut sudah masuk kedalam wilayah Provinsi Jawa Tengah. Hasil wawancara dengan Bapak Haryono selaku Kepala Sub Bidang Pajak Badan Pengelola Pendapatan Daerah (BPPD) Provinsi Jawa Tengah, terdapat beberapa faktor yang dapat mempengaruhi Kepatuhan membayar PKB antara lain :

\section{Faktor Kesadaran Masyarakat}

Tingkat Kesadaran masyarakat yang tinggi akan mendorong semakin banyak masyarakat memenuhi kewajibannya sebagai wajib pajak, melaporkan dan membayar pajaknya dengan benar sebagai wujud tanggung jawab berbangsa dan bernegara. Apabila kesadaran masyarakat atas perpajakan masih rendah maka akan menyebabkan banyaknya potensi pajak yang tidak dapat diperoleh. Kesadaran wajib pajak ini akan berpengaruh positif terhadap tingkat kepatuhan wajib pajak pribadi. Kesadaran tentang pajak yang tumbuh akan membuat para wajib pajak (WP) mempersiapkan berbagai hal yang dibutuhkan untuk memenuhi kewajiban perpajakannya, dalam hal ini masyarakat yang memiliki kendaraan bermo-tor akan menyadari untuk membayar PKB atas kendaraan yang dimilikinya.

\section{Faktor Pengetahuan tentang Pajak}

Faktor pengetahuan sangat penting dalam membantu wajib pajak melaksanakan kewajibannya, khususnya penge-tahuan dasar tentang perpajakan Masyarakat pada umumnya belum banyak yang mengerti informasi tentang pajak. Tanpa adanya pengetahuan, wajib pajak akan mengalami kesulitan dalam memenuhi kewajibannya seperti mengisi formulir pajak, membayar pajak dan melaporkan kewajiban perpajakannya. Era keterbukaan informasi inilah hal yang paling penting bagi pemerintah untuk terus melakukan sosialisasi kepada masyarakat tentang PKB. Pemerintah provinsi dapat memanfaatkan media sosial, media cetak, serta media elektronik dalam melakukan sosialisasi, sehingga informasi tentang PKB dapat diterima dengan baik oleh masyarakat.

\section{Faktor Moral Wajib Pajak}

Moralitas merupakan salah satu pemicu yang sangat penting dalam meningkatkan tingkat kepatuhan wajib pajak. Moralitas berkaitan dengan norma individu. Moralitas dapat berupa perasaan bersalah yang dimiliki oleh individu, dimana terdapat perbedaan di setiap individu mengenai moralitas ini. Individu yang sudah menyadari akan adanya kewajiban, dalam hal ini kewajiban tentang pajak kendaraan bermotor akan berpengaruh terhadap tingkat kepatuhannya terhadap pem-bayaran PKB, sehingga dapat dikatakan bahwa moral yang kuat akan meningkatkan tingkat kepa-tuhan wajib pajak.

Menurut Ibu Sulistiyati selaku Kepala Sub Bidang Pengembangan Potensi Pendapatan Badan Pengelola Pendapatan Daerah (BPPD) Provinsi Jawa Tengah antara lain : (1) Pelayanan fiskus atau petugas pajak dalam melayani kebutuhan wajib pajak ; (2) Sosialisasi mengenai PKB ; (3) Persepsi atas penggunaan uang pajak secara transparan dan akuntabel ; (4) Efektivitas sistem perpajakan yang dapat mempengaruhi kepatuhan wajib pajak dalam melaksanakan kewajibannya sebagai warga negara.

Usaha untuk meningkatkan kepatuhan wajib pajak dalam memenuhi kewajiban perpajakannya, kualitas pelayanan pajak harus ditingkatkan oleh aparat pajak. Oleh karena itu kualitas pelayanan perlu ditingkatkan untuk mem-berikan kenyamanan dan pandangan yang baik dari wajib 
pajak. Pelayanan petugas pajak yang kooperatif, jujur, menegakkan aturan perpajakan, tidak mempersulit, dan tidak mengecewakan wajib pajak diharapkan mampu mengatasi masalah kepatuhan wajib pajak. Keramahan petugas pajak dan kemudahan dalam sistem informasi perpajakan termasuk dalam pelayanan perpajakan tersebut.

Pemerintah dapat terus meningkatkan kualitas pelayanan yang diberikan kepada wajib pajak dengan membuat sebuah sistem. Hal ini diharapkan dapat memudahkan wajib pajak dalam membayar dan melaporkan kewajiban pajaknya. Kemudahan dari sistem perpajakan dapat berjalan dengan baik dan dimengerti masyarakat, sosialisasi dengan menggunakan berbagai media mengenai perpajakan. Manfaat dari sosialisasi tersebut, masyarakat akan lebih memahami masalah - masa-lah tentang perpajakan, kemudahan yang bisa didapat, dan memahami peraturan perpajakan yang sering berubah-ubah, dengan pemahaman yang baik diharapkan akan meningkatkan kepatuhan wajib pajak.

Kebijakan dan Strategi Pemerintah Provinsi Jawa Tengah untuk Meningkatkan Penerimaan Pajak Kendaraan Bermotor (PKB)

Kebijakan Pemerintah Provinsi Jawa Tengah dapat dilihat dari Peraturan Daerah (PERDA) Provinsi Jawa Tengah No 2 Tahun 2011 Tentang Pajak Daerah yang mencakup pengaturan jenis pajak dan administrasi pajak daerah yaitu :

Pajak Kendaraan Bermotor (PKB)

Objek Pajak Kendaraan Bermotor adalah kepemilikan dan/atau penguasaan Kendaraan Bermotor. Pengertian Kendaraan Bermotor adalah kendaraan bermotor beroda beserta gandengannya yang dioperasikan di semua jenis jalan darat dan kendaraan bermotor yang dioperasikan di air dengan ukuran isi kotor GT 5 (lima Gross Tonnage) sampai dengan GT 7 (tujuh Gross Tonnage). Dikecualikan dari pengertian Kendaraan Bermotor sebagaimana dimaksud dalam Pasal 4 ayat (2).

Kereta api, kendaraan bermotor yang semata-mata digunakan untuk keperluan pertahanan dan keamanan negara, kendaraan bermotor yang dimiliki dan/atau dikuasai kedutaan, konsulat, perwakilan negara asing dengan asas timbal balik dan lembaga - lembaga internasional yang memperoleh fasilitas pembebasan pajak dari Pemerintah, kendaraan bermotor yang dimiliki dan/atau dikuasai Pabrikan atau import yang semata-mata untuk dipamerkan dan dijual, kendaraan bermotor yang dikuasai Negara sebagai barang bukti, yang disegel atau disita, serta kendaraan ber-motor yang dioperasikan di air (Perda Jateng No 2 Th 2011).

Subjek Pajak Kendaraan Bermotor adalah orang pribadi atau Badan yang memiliki dan/atau menguasai Kendaraan Bermotor. Wajib Pajak Ken- daraan Bermotor adalah orang pribadi atau Ba-dan yang memiliki Kendaraan Bermotor. Dalam hal Wajib Pajak Badan, kewajiban perpajakannya diwakili oleh pengurus atau kuasa Badan tersebut (Perda Jateng No 2 Th 2011).

Nilai Jual Kendaraan Bermotor ditentukan berdasarkan Harga Pasaran Umum atas suatu Kendaraan Bermotor. Harga Pasaran Umum dimaksud adalah harga rata-rata yang diperoleh dari berbagai sumber data yang akurat. Nilai Jual Kendaraan Bermotor ditetapkan berdasarkan Harga Pasaran Umum pada minggu pertama bulan Desember Tahun Pajak sebelumnya. Dalam hal Harga Pasaran Umum suatu Kendaraan Bermotor tidak diketahui, Nilai Jual Kendaraan Bermotor dapat ditentukan berdasarkan sebagian atau seluruh faktor - faktor : a) Harga Kendaraan Bermotor dengan isi silinder dan/atau satuan tenaga yang sama ; b) Penggunaan Kendaraan Bermotor untuk umum atau pribadi ; c) Harga Kendaraan Bermotor dengan merek Kendaraan Bermotor yang sama ; d) Harga Kendaraan Bermotor dengan tahun pembuatan Kendaraan Bermotor yang sama ; e) Harga Kendaraan Bermotor dengan pembuat Kendaraan Bermotor ; f) Harga KendaraanBermotor dengan Kendaraan Bermotor sejenis ; g) Harga Kendaraan Bermotor berdasarkan dokumen Pemberitahuan Impor Barang (PIB).

Bobot sebagaimana dimaksud pada ayat (1) huruf $b$ dihitung berdasarkan faktor - faktor : a) tekanan gandar, yang dibedakan atas dasar jumlah sumbu/as, roda, dan berat Kendaraan Bermotor ; b) jenis bahan bakar Kendaraan Bermotor yang dibedakan menurut solar, bensin, gas, listrik, tenaga surya, atau jenis bahan bakar lainnya ; c) jenis, penggunaan, tahun pembuatan, dan ciri-ciri mesin Kendaraan Bermotor yang dibedakan berdasarkan jenis mesin 2 tak atau 4 tak, dan isi silinder. Khusus untuk kendaraan yang dioperasikan di atas air, dasar pengenaan pajak merupakan hasil penjumlahan nilai jual mesin dengan nilai jual body/rangka kendaraan air.

Tarif Pajak Kendaraan Bermotor pribadi, badan ditetapkan sebesar 1,5 \% (satu koma lima persen) untuk kepemilikan kendaraan pertama. Tarif Pajak Kendaraan Bermotor pribadi dihitung se-cara progresif dan ditetapkan sebagai berikut : a) untuk kepemilikan kendaraan bermotor pertama sebesar $1,5 \%$; b) untuk kepemilikan kendaraan bermotor kedua sebesar $2 \%$ c) untuk kepemilikan kendaraan bermotor ketiga sebesar $2,5 \%$; d) untuk kepemilikan kendaraan bermotor keempat sebesar $3 \%$; e) untuk kepemilikan kendaraan bermotor kelima sebesar 3,5\%. 
berikut ; a) Kendaraan Bermotor umum sebesar $1 \%$; b) Kendaraan Bermotor lembaga sosial Tarif Pajak Kendaraan Bermotor umum, lembaga sosial keagamaan, Pemerintah Pusat/TNI-/POLRI, dan Pemerintah Daerah ditetapkan sebagai Keagamaan, Pemerintah Pusat/TNI/POLRI, Pemerintah Daerah sebesar 0,5\%. Tarif Pajak Kendaraan Bermotor alat-alat berat dan alat - alat besar sebesar $0,2 \%$ (nol koma satu persen) dan paling tinggi sebesar $0,2 \%$. Tarif Pajak Kendaraan di air sebesar $1,5 \%$. Pendaf-taran, Pelaporan dan Wilayah Pungutan Pajak

Setiap Wajib Pajak yang memiliki dan/atau menguasai kendaraaan wajib mendaftarkan / registrasi kendaraannya pada instans iyang ditunjuk di Daerah. Batas waktu untuk mendaftarkan kendaraan dimaksud ditentukan sebagai berikut : a) Bagi kendaraan baru atau yang belum pernah terdaftar, selambat-lambatnya 14 (empat belas) hari sejak saat kepemilikan dan/atau penguasaan ; b) Bagi kendaraan pindahan yang telah terdaftar di Daerah lain, selambat-lambatnya 30 (tiga puluh) hari sejak diterbitkannya Dokumen Administrasi pemindahan tempat pengoperasian kendaraan. Kendaraan yang telah terdaftar di Daerah wajib untuk didaftarkan ulang paling lambat pada saat berakhirnya masa pajak.

Setiap Objek Pajak yang didaftarkan atau telah terdaftar, wajib dilaporkan oleh Wajib Pajak atau kuasanya pada saat pendaftaran atau setiap kali masa pajak berakhir. Pelaporan tersebut harus diisi dengan jelas, benar dan lengkap serta ditandatangani oleh Wajib Pajak atau orang yang diberi kuasa, termasuk apabila terjadi perubahan atas Kendaraan Bermotor dalam masa pajak, baik perubahan bentuk, fungsi maupun penggantian mesin. Tata cara pelaporan objek pajak diatur lebih lanjut dengan Peraturan Gubernur. Wilayah pemungutan pajak adalah di Wilayah Daerah.

Masa Pajak dan Saat Terutang Pajak

Masa pajak ditetapkan sebagai berikut : a) Kendaraan yang baru pertama kali terdaftar masa pajak adalah 12 (dua belas) bulan berturut - turut dari saat pendaftaran. b) Kendaraan daftar ulang masa pajak 12 (dua belas) bulan berturut-turut sesuai dengan masa pajak tahun sebelumnya ; c) Kendaraan lelang/dump milik Pemerintah, TNI/POLRI masa Pajak 12 (dua belas) bulan sejak pendaftaran dengan kewajiban pajak yang timbul atau seharusnya terutang sejak saat objek dikuasai dan/atau dimiliki berdasarkan tanggal penetapan keputusan lelang/dump ; d) Kendaraan yang melanggar ketentuan batas waktu pendaftaran dalam jangka waktu lebih dari 1 (satu) bulan.

Penetapan PKB
Berdasarkan perlaporan sebagaimana dimaksud dalam Pasal 12 ayat (2) dan ayat (3), Gubernur atau Pejabat yang ditunjuk menetapkan besarnya Pajak Kendaraan Bermotor, dengan menerbitkan

SKPD atau dokumen lain yang dipersamakan. Bentuk, isi, kualitas dan ukuran SKPD atau dokumen lain yang dipersamakan, diatur dengan Peraturan Gubernur. Pelanggaran batas waktu pendaftaran sebagaimana dimaksud dalam Pasal 11, Pasal 12 dan Pasal 15 dikenakan sanksi administrasi berupa denda sebesar $25 \%$ (dua puluh lima persen) dari pajak yang terutang. Perubahan fungsi atas kendaraan yang mengakibatkan terjadinya penuru-nan pokok pajak dalam satu masa pajak dapat dikompensasikan ke masa pajak berikutnya. Tata cara perhitungan kompensasi akan diatur lebih lanjut dengan Peraturan Gubernur.

\section{Bea Balik Nama Kendaraan Bermotor (BBNKB)}

Pajak yang dipungut atas penyerahan kendaraan bermotor dinamakan BBNKB. Objek BBNKB adalah penyerahan kepemilikan Kendaraan Bermotor. Termasuk dalam pengertian Kendaraan Bermotor adalah kendaraan bermotor beroda beserta gandengannya, yang dioperasikan disemua jenis jalan darat dan kendaraan bermotor yang dioperasikan diair dengan ukuran isi kotor GT 5 (lima Gross Tonnage) sampai dengan GT7 (tujuh Gross Tonnage). Subjek Pajak BBNKB meliputi orang pribadi atau badan yang dapat menerima penyerahan kendaraan bermotor. Wajib Pajak BBNKB meliputi orang pribadi atau badan yang dapat menerima penyerahan kendaraan bermotor.

\section{Dasar Pengenaan, Tarif dan Perhitungan BBNKB}

Dasar pengenaan BBNKB adalah Nilai Jual Kendaraan Bermotor. Tarif BBNKB ditetapkan sebagai berikut : 1) penyerahan pertama untuk kendaraan bermotor roda dua atau lebih sebesar 10\% (sepuluh persen) ; 2) penyerahan kedua dan seterusnya sebesar $1 \%$ (satu persen). Tarif BBNKB untuk kendaraan bermotor alat berat dan alat-alat besar yang tidak menggunakan) jalan umum, tarif pajak ditetapkan sebagai berikut : a) penyerahan pertama sebesar $0,75 \%$ (nol koma tujuh puluh lima persen); b) penyerahan kedua dan seterusnya sebesar 0,075\% (nol koma nol tujuh puluh lima persen). Tarif BBNKB yang dioperasikan di air ditetapkan sebagai berikut: a) untuk penyerahan pertama sebesar 7,5\% (tujuh koma lima persen); b) untuk penyerahan kedua dan seterusnya sebesar $1 \%$ (satu persen). Besaran pokok Pajak BBNKB yang terutang dihitung dengan cara mengalikan tarif sebagaimana dimaksud dalam Pasal 25 dengan 
dasar pengenaan pajak sebagaimana dimaksud dalam Pasal 6 ayat (10).

\section{Pendaftaran, Pelaporan dan Wilayah Pemungutan} Pajak

Orang pribadi atau ahli warisnya atau badan, Pemerintah/TNI/Polri dan Pemerintah Daerah yang menerima penyerahan atau yang dapat dianggap menerima penyerahan kendaraan wajib melaporkan secara tertulis kepada instansi yang ditunjuk selambat - lambatnya : a) 14 (empat belas) hari sejak penyerahan terhadap kendaraan baru ; b) 30 (tiga puluh) hari sejak penyerahan terhadap Kendaraan yang terdaftar di Daerah atau sejak diterbitkannya dokumen administrasi pemin-dahan tempat pengoperasian kendaraan terhadap kendaraan pindahan yag terdaftar di Daerah lain atau bagi kendaraan yang dianggap sebagai penyerahan. Setiap kendaraan yang mengalami perubahan serta penggantian body, spesifikasi teknik dan/atau penggantian mesin wajib melaporkan secara tertulis kepada Gubernur atau pejabat yang ditunjuk, dalam waktu selambat lambatnya 30 (tiga puluh) hari sejak dikeluarkannya dokumen administrasi dan perubahan. Pelaporan sebagaimana dimaksud pada ayat (1) dan ayat (2) harus diisi dengan jelas, benar dan lengkap serta ditandatangani oleh wajib pajak atau orang yang diberi kuasa olehnya. Tata cara pelaporan diatur lebih lanjut dengan Peraturan Gubernur.

Pemasukan Kendaraan dari luar daerah harus dilengkapi bukti pelunasan PKB dan BBNKB dari daerah asalnya berupa Surat Keterangan fiskal antar daerah. Orang pribadi, Badan, Pemerintah / TNI / Polri, Pemerintah Daerah yang menyerahkan Kendaraan wajib melaporkan kepada instansi yang ditunjuk di Daerah atas terjadinya penyerahan hak milik selambat-lambatnya 30 (tiga puluh) hari sejak saat penyerahan kendaraan. Laporan penyerahan kendaraan bermotor sekurang-kurangnya memuat : a) nama dan alamat lengkap orang pribadi, badan, Pemerintah/TNI/Polri, Pemerintah Daerah yang menyerahkan dan menerima penyerahan ; b) tanggal, bulan dan tahun penyerahan ; c) nomor polisi kendaraan bermotor ; d) lampiran fotokopi surat tanda nomor kendaraan bermotor ; e) khusus untuk kendaraan di air ditambahkan pas dan nomor pas kapal. Wilayah pemungutan Pajak adalah di Wilayah Daerah.

BBNKB saat terutang dan Penetapan BBNKB

Saat pajak terutang adalah sejak diterbitkannya SKPD atau dokumen lain yang dipersamakan. Penetapan BBNKB berdasarkan pelaporan sebagaimana dimaksud Pasal 27 ayat (1) dan ayat (2) Gubernur atau Pejabat yang ditunjuk menetapkan besarnya Pajak BBNKB, dengan menerbitkan SKPD atau dokumen lain yang dipersamakan. Bentuk isi, kualitas dan ukuran SKPD atau dokumen lain yang dipersamakan sebagaimana dimaksud pada ayat (1) diatur lebih lanjut dengan Peraturan Gubernur. Pelanggaran batas waktu sebagaimana dimaksud dalam Pasal 33 ayat (1) huruf a dan huruf b dikenakan sanksi administrasi berupa denda sebesar 25\% (dua puluh lima persen) dari pokok pajak BBNKB. Tetapi hal ini dengan Kebijakan Penghapusan Denda Pajak Berda-sarkan Peraturan Gubenur Nomor 44 Tahun 2017 tentang Penghapusan Denda Pajak dan Balik Nama Kendaraan Bermotor di Dinas Pendapatan Daerah Provinsi Jawa Tengah sehingga, denda Pajak dan Balik Nama Kendaraan Bermotor tidak perlu lagi.

Upaya Pemerintah Provinsi Jawa Tengah dalam Memotivasi Wajib Pajak untuk Membayar Pajak Kendaraan Bermotor (PKB)

Membayar pajak merupakan kewajiban setiap warga negara. Warga negara yang taat, sudah seharusnya memiliki kesadaran untuk membayar pajak. Sadar pajak tidak hanya diartikan taat membayar pajak, namun diharapkan bisa paham dan mengerti hal - hal yang terkait dengan pajak. Masyarakat harus sadar berapa pajak yang telah dipungut kemudian dialokasikan kembali untuk pembangunan. Saat ini pajak merupakan suatu hal yang wajib untuk dipahami dan dimengerti, karena pajak sudah menjadi bagian penting dalam perekonomian. Pemerintah menyadari bahwa pemerintah harus melakukan sosialiasi pentingnya pajak bagi pembangunan negara.

Salah satu sumber perolehan Anggaran Pendapatan Belanja Negara (APBN) di Indonesia adalah pajak. Pembayaran pajak sangat penting bagi negara untuk pelaksanaan dan peningkatan pembangunan nasional, serta untuk kesejahteraan rakyat. Peran pajak sangat besar dalam suatu negara, termasuk di negara Indonesia sebagai negara berkembang yang menggunakan pajak sebagai salah satu pendapatan utama untuk membiayai segala macam kebutuhan.Tidak dapat dibayangkan bagaimana kondisi keuangan negara tanpa kontribusi dari pajak sebagai sumber utama penghasilan bagi keuangan negara. Pembangunan tidak dapat dijalankan apabila sumber pendanaannya tidak tersedia. Kesulitan pendanaan pembangunan akan mengakibatkan upaya meningkatkan kesejahteraan rakyat sulit diwujud-kan.

Pajak menjadi hal yang sangat penting, namun masyarakat masih kurang menyadari sehingga tingkat kepatuhan terhadap pajak masih tergolong sangat rendah. Rendahnya tingkat kepatuhan wajib pajak ini juga terjadi di wilayah Provinsi Jawa Tengah. Permasalahan ini selalu muncul dari tahun ke tahun berikutnya. Meski telah melakukan pembenahan untuk menaikkan tingkat kepatuhan wajib pajak, namun masih terdapat beberapa kendala. Kendala yang masih dihadapi 
yaitu, kondisi ekonomi dan besaran penghasilan dari wajib pajak, tingkat pendidikan wajib pajak, permasalahan korupsi pajak, pelayanan yang kurang memuaskan, mekanisme pembayaran yang berbelit, pungli di kantor samsat, dan motivasi wajib pajak untuk membayar pajak.

Upaya - upaya yang telah dilakukan untuk meningkatkan tingkat kepatuhan wajib pajak dalam membayar PKB berdasarkan hasil kajian identifikasi faktor keterlambatan pembayaran PKB yang dilakukan oleh Badan Pengelola Pendapatan Daerah (BPPD) Provinsi Jawa Tengah antara lain : a) Melakukan sosialisasi di berbagai media yaitu, media elektronik melalui televisi, media cetak, iklan di media massa, pemasangan spanduk dan baliho di titik titik strategis, dan media sosial; b) Melakukan sosialisasi kegiatan sadar pajak, sosialisasi dapat dilakukan saat kegiatan keagamaan ataupun kegiatan hiburan dan seni; c) Menambah titik titik pembayaran PKB supaya dapat di akses oleh masyarakat yang berada di wilayah pedesaan seperti kelurahan maupun kecamatan; d) Melakukan kerjasama dengan institusi keuangan untuk mempermudah proses pembayaran seperti minimarket, kantor pos, mesin ATM, maupun aplikasi berbasis android (SAKPOLE) sehingga pembayaran PKB tidak harus dilakukan di kantor SAMSAT; e) Melakukan pembenahan terhadap petugas pelayan pajak, sehingga masyarakat dapat dilayani dengan cepat dan ramah; f) Menerapkan zona bebas pungli di Kantor - Kantor SAMSAT; g) Memberikan stimulus kepada masyarakat seperti memberikan program bebas denda, bebas balik nama kendaraan bermotor dan memberikan hadiah undian kepada para wajib pajak yang patuh dalam membayar PKB; h) Melakukan update data PKB secara berkala; i) Melakukan penghapusan terhadap kendaraan yang sudah rusak atau mangkrak, sehingga tidak membebani target PKB.

\section{SIMPULAN}

Berdasarkan uraian dalam pembahasan dan análisis hasil penelitian, maka dapat ditarik kesimpulan sebagai berikut : 1) Kepatuhan Wajib Pajak Kendaraan Bermotor Dalam Kaitannya Dengan Kebijakan Penghapusan Denda Pajak Berdasarkan Peraturan Gubenur Nomor 44 Tahun 2017 tentang Penghapusan Denda Pajak dan Balik Nama Kendaraan Bermotor di Badan Pengelola Pendapatan (BPPD) Provinsi Jawa Tengah. Kepatu-han pajak (tax compliance) sebagai indikator peran masyarakat dalam memenuhi kewajiban perpajakan masih sangat rendah $\mathrm{Hal}$ ini dapat dilihat masih rendahnya peran wajib pajak dalam membayar pajak kenda- raan bermotornya. Semakin banyak jumlah wajib pajak kendaraan bermotor, seharusnya diiringi dengan peningkatan kepatuhan waijb pajak kendaraan bermotor; 2) Kepatuhan pajak (tax compliance) adalah wajib pajak mempunyai kesediaan untuk memenuhi kewajiban pajaknya sesuai dengan aturan yang berlaku tanpa perlu diadakannya pemeriksaan, investigasi sek-sama, peringatan ataupun ancaman, dalam penera-pan sanksi baik hukum maupun administrasi. Diharapkan kebijakan penghapusan denda pajak yang berdasarkan Peraturan Gubenur Nomor 44 Tahun 2017 tentang Penghapusan Denda Pajak dan Balik Nama Kendaraan Bermotor di Dinas Pendapatan Daerah Provinsi Jawa Tengah. dan pembebasan BBNKB dapat mendorong masyarakat untuk wajib Pajak Kendaraan Bermotor segera melunasi pajaknya; 3) Faktor yang Mempengaruhi Kepatuhan Membayar Pajak Kendaraan Bermotor Dalam Kaitannya Dengan Kebijakan Penghapusan Denda Pajak Berdasarkan Peraturan Gubenur Nomor 44 Tahun 2017 tentang Penghapusan Denda Pajak dan Balik Nama Kendaraan Bermotor di Badan Pengelola Pendapatan (BPPD) Provinsi Jawa Tengah adalah Faktor Kesadaran masyarakat, Faktor meningkatkan kewajiban moral wajib pajak, dan Faktor pengetahuan tentang pajak.

Upaya Apa Yang Seharusnya Dilakukan Oleh Badan Pengelola Pendapatan (BPPD) Provinsi Jawa Tengah dalam Memotivasi Masyarakat Untuk Membayar Pajak dan meningkatkan Tingkat Kepatuhan dalam membayar Pajak. Motivasi pada akhirnya berpengaruh terhadap kepatuhan wajib pajak dalam memenuhi kewajiban perpajakannya. Motivasi dari wajib pajak adalah kesadaran pajak dari wajib pajak, tingkat kesadaran akan membayar pajak didasarkan oleh tingkat kepatuhan wajib pajak yang berpijak pada tingginya kesadaran hukum dalam membayar pajak. Terdapat pengaruh yang signifykan antara motivasi dengan kepatuhan wajib pajak. Motivasi membayar pajak adalah kekuatan potensial yang ada dalam diri wajib pajak yang melatarbelakangi seorang wajib pajak untuk mem-bayar pajak. Berdasarkan kajian yang dilakukan untuk identifikasi faktor keterlambatan pemba-yaran PKB yang dilakukan oleh Badan Pengelola Pendapatan Daerah (BPPD) Provinsi Jawa Tengah diperoleh beberapa rekomendasi seperti mening-katkan sosialiasi, mempermudah pembayaran PKB, menghilangkan pungli, update data PKB,dan pelaya-nan yang cepat dan ramah.

Penelitian ini memiliki keterbatasan yaitu hanya terbatas pada pencarian faktor - faktor yang mempengaruhi Kepatuhan Wajib pajak dan Upaya yang dilakukan untuk Memotivasi Wajib Pajak, sehingga perlu dilakukan penelitian lanjutan untuk 
meningkatkan Tingkat Kepatuhan Wajib Pajak. Penelitian ini juga dapat dijadikan bahan kajian untuk memahami permasalahan terkait dengan perencanaan target penerimaan pajak kendaraan bermotor dari pemerintah Provinsi Jawa Tengah yaitu dengan menambah beberapa variabel seperti kemampuan bayar yang dilihat dari Faktor Pendapatan Wajib Pajak, Reward and Punishment sebagai stimulus Wajib Pajak untuk membayar PKB, serta variabel tentang Sosialisasi yang perlu dilakukan secara masif oleh Pemerintah Provinsi Jawa Tengah

\section{DAFTAR PUSTAKA}

Abdurrahman, 1987. Beberapa Pemikiran tentang Otonomi Daerah, Jakarta: Media Sarana Press.

Achmad Tjahyono \& Muh. Taufik Husein, 2002. Perpajakan di Indonesia; Yogyakarta : YKPM.

Amir Santoso,1992. Analisa Kebijakan Publik : Suatu Pengantar, Jurnal Ilmu Politik No. 3, Jakarta : Gramedia.

Amrah Muslimin, 1982. Aspek-aspek Hukum Otonomi Daerah, Bandung : Alumni.

Anderson, James E. 1979. Public Policy Making, New York: Holt, Rinehart and Winston.

Arifin P Soeria Atmaja, 2009. Keuangan Publik dalam Perspektif Hukum, Teori, Kritik, dan Praktik, Jakarta : Rajawali Pers.

Bagir Manan, 1990. Hubungan Antara Pusat dan Daerah Berdasarkan Azas Desentralisasi Menurut UUD 1945. Bandung : Universitas Padjadjaran.

Connolly, Sara and Alistair Munro, 1999. Economics of The Public Sector, New York : Prentice Hall.

Davey, K.J. 1988. Pembiayaan Pemerintah Daerah:Praktek-praktek Iinternasional dan Relevansinya Bagi DUnia Ketiga, diterjemahkan oleh Amanullah, Jakarta : UI Press.

Dye., Thomas R. 1978. Understanding public policy, Prentice Hall, Inc. Englewood Cliffs. Easton, David. 1953. The Political System, New York : Knopf.

Erly Suandi, 2000. Hukum Pajak, Jakarta : Salemba Empat.

Eti Rochaety, dkk. Sistem Informasi Manajemen Pendidikan, Bumi Akara, Jakarta, 2010.

Friedrick, Carl J. Friedrick, 1963. Man and His Government, New York: Mc Graw Hill. George C. Edwards III, Ira Sharkansky, 1978. The Policy Predicament, San Fransisco: W.H. Freeman and Company,.

Gunawan, B., \& Hapsari, G. Y. (2018). Analisis Penilaian Aset Tetap PT. Garuda Indonesia (Persero) Tbk dalam Meminimalkan Beban Pajak Penghasilan dan Upaya Mengontrol
Permodalan. Jati: Jurnal Akuntansi Terapan Indonesia, 1(2), 82-90.

Irawan Soejito, 1981. Hubungan Pemerintah Pusat dan Pemerintah Daerah, Jakarta : Bina Aksara.

Jenkins, W.I.1978. Public Analysis, Oxford: Martin Robertson.

J. Kaloh, 2002. Mencari Bentuk Otonomi Daerah, Suatu Solusi Dalam Menjawab

Kebutuhan Lokal dan Tantangan Global, Jakarta : Rineka Cipta.

J.S. Badudu, 1994. Sutan Mohammad Zen, Kamus Umum Bahasa Indonesia, Jakarta ; Pustaka Sinar Harapan.

Krishna D. 2003. Darumurti, Umbu Rauta, Otonomi Daerah, Perkembangan Pemikiran, Pengaturan dan Pelaksanaan, Bandung : Citra Aditya Bakti.

Laswell, Harold D., Abraham Kaplan, 1970. Power and Society, New Haven: Yale University Press.

Miyasto, 1991. Pajak Penjualan dan Pajak Pertambahan Nilai. Studi Mengenai Dampak terhadap Harga, Penerimaan dan Struktur. Yogyakarta: Universitas Gadjah Mada.

Muqodim, 1999. Perpajakan Buku Satu, Yogyakarta : UII Press.

Peraturan Bersama Menteri Keuangan dan Menteri Dalam Negeri Nomor 213/PMK.07/2010, Nomor 58 TAHUN 2010 Tentang Tahapan Persiapan.

Perda No 2 Tahun 2011 Tentang Pajak Daerah Provinsi Jawa Tengah.

Peraturan Gubernur No 21 Tahun 2017.

R. Kaho, 1995. Prospek Otonomi Daerah di Negara Republik Indonesia, Jakarta : Raja Grafindo Persada.

Rochmat Soemitro, 2004. Asas dan Dasar Perpajakan 2. Bandung : PT Refika Aditama.

Ronny Hanitijo Soemitro, 1994. Metodologi Penelitian Hukum dan Jurimetri, Cetakan Kelima, Jakarta : Ghalia Indonesia.

Soerjono Soekanto \& Sri Mamudji, 2001. Penelitian Hukum Normatif, Suatu Tinjauan Singkat, Jakarta : Rajawali Pers.

R. Santoso Brotodihardjo, 2003. Pengantar Ilmu Hukum Pajak, Cet Pertama Edisi Keempat, Bandung: PT. Refika Aditama.

Sally M. Jones, 2002. Principles of Taxation, New York:Mc Graw Hill.

Sommerfeld et al. 1994. Concepts of Taxation, San Diego: The Dryden Press.

Sujamto, 1979/1980. Latar Belakang Otonomi Daerah Yang Nyata Dan Bertanggungjawab Dititikberatkan Pada Daerah Tingkat II. Pusat Penelitian dan Pengembangan Pemerintah Daerah. Badan Penelitian dan Pengembangan, Jakarta : Departemen dalam Negeri. 
Undang - Undang Nomor 34 Tahun 2000 Tentang Perubahan Terhadap Undang-Undang.

Undang - Undang Nomor 18 Tahun 1997 tentang Pajak Daerah dan Retribusi Daerah.

Undang - Undang Nomor 17 Tahun 2003 tentang Keuangan Negara.

Undang - Undang Nomor 32 Tahun 2004 Tentang Pemerintahan Daerah.

Undang - Undang Nomor 28 Tahun 2009 Tentang Pajak dan Retribusi Daerah. 